\title{
Interaction of Diphenylhydantoin (Phenytoin) and Phenobarbital with Hormonal Mediation of Fetal Rat Bone Resorption In Vitro
}

\author{
Theodore J. Hahn, Cheryl R. Scharp, Catherine A. Richardson, \\ Linda R. Halstead, Arnold J. Kahn, and Steven L. Teitelbaum, \\ Division of Bone and Mineral Metabolism, Departments of Medicine \\ and Pathology, Washington University, The Jewish Hospital of St. Louis, \\ St. Louis, Missouri 63110
}

A B S T R A C T Chronic administration of high doses of anticonvulsant drugs frequently produces classic osteomalacia with bone histologic changes characteristic of increased parathyroid hormone (PTH) effect in man. However, several reports have documented defects in calcified tissue metabolism suggestive of an end-organ resistance to PTH after chronic anticonvulsant drug therapy. To examine the direct action of anticonvulsant drugs on bone resorption, we investigated the effects of diphenylhydantoin (phenytoin) (DPH) (100-200 $\mu \mathrm{g} / \mathrm{ml})$ and phenobarbital (10-400 $\mu \mathrm{g} / \mathrm{ml}$ ) on basal and hormonally mediated resorption 5-day cultures of fetal rat forelimb rudiments. In this system both drugs significantly inhibited basal and PTH-stimulated ${ }^{45} \mathrm{Ca}$ and $\left[{ }^{3} \mathrm{H}\right]$ hydroxyproline release, as well as 1,25-dihydroxyvitamin $\mathrm{D}_{3}$-stimulated ${ }^{45} \mathrm{Ca}$ release. The effects of DPH and phenobarbital were additive, with DPH exhibiting a several-fold more potent inhibitory effect than phenobarbital. Whereas DPH exhibited a striking synergism with the inhibitory effects of human calcitonin (HCT) on PTH-induced resorption, the effect of phenobarbital was merely additive to that of HCT. PTH and PTH plus HCT-induced increases in bone cyclic AMP (cAMP) content were significantly inhibited by DPH but not by phenobarbital. However, in contrast to effects on ${ }^{45} \mathrm{Ca}$ release, DPH inhibition of cAMP generation was not accentuated in the presence of HCT. It is concluded that: $(a)$ both DPH and phenobarbital can directly inhibit basal and hormonally stimulated bone resorption, with DPH being much more potent in this

Dr. Hahn is the recipient of a National Institutes of Health Research Career Development Award NS70540 and grant AM20521.

Received for publication 12 October 1977 and in revised form 14 March 1978. regard; (b) DPH appears to inhibit bone resorption via a cAMP-independent mechanism and has an additional suppressive effect on PTH-induced cAMP generation; and $(c)$ the synergistic interaction of DPH and HCT in inhibiting ${ }^{45} \mathrm{Ca}$ release occurs at a site independent of cAMP generation.

\section{INTRODUCTION}

It is well recognized that chronic administration of anticonvulsant drugs can produce a variety of disorders of vitamin D, mineral, and bone metabolism. Hypocalcemia, reduced serum 25 -hydroxyvitamin $D$ concentrations, elevated serum immunoreactive parathyroid hormone (PTH) ${ }^{1}$ levels, reduced bone mass, and histologic evidence of osteomalacia have been reported in $10-60 \%$ of various anticonvulsant drug-treated populations (1-6). From the observation that administration of phenobarbital and diphenylhydantoin (phenytoin) (DPH) to humans and animals leads to induction of liver microsomal oxidase enzymes, with a consequent increased rate of catabolism of vitamin $\mathrm{D}$ and 25-hydroxyvitamin $\mathrm{D}$ to polar, presumably inactive products $(7,8)$, it has been generally accepted that a reduction in the circulating levels of biologically active vitamin $D$ metabolites plays a significant role in producing the derangements of mineral metabolism seen in this disorder.

On the other hand, several clinical studies have demonstrated that chronic DPH administration can also produce effects suggestive of end-organ resistance to the effects of PTH. Radiographic surveys of denti-

\footnotetext{
${ }^{1}$ Abbreviations used in this paper: cAMP, cyclic AMP; 1,25- $(\mathrm{OH})_{2} \mathrm{D}, 1,25$-dihydroxyvitamin $\mathrm{D}_{3}$; DPH, diphenylhydantoin (phenytoin); HCT, human calcitonin; PTH, synthetic parathyroid hormone $(1-34)$.
} 
tion in patients receiving chronic DPH therapy have demonstrated a markedly increased incidence of root abnormalities, characteristic of those seen in hypoparathyroidism and pseudohypoparathyroidism $(9,10)$. Moreover, calvarial thickening, another feature of chronic hypoparathyroid states, has been observed with increased frequency after prolonged DPH administration (11). In addition, there is experimental evidence which suggests that anticonvulsant drugs may indeed have direct effects on mineral metabolism. Koch et al. (12) have reported that DPH appears to directly inhibit intestinal calcium transport in the rat and Harris et al. (9) have demonstrated that DPH can inhibit parathyroid extract-induced ${ }^{45} \mathrm{Ca}$ release from mouse calvaria in vitro.

The purpose of the present studies was to examine the direct effects of DPH and phenobarbital on basal and hormone-mediated resorption and cyclic nucleotide generation in fetal rat long bone rudiments maintained in culture. Our results indicate that both drugs directly affect indices of bone resorption and that DPH, in particular, interacts significantly with hormonally mediated resorption processes.

\section{METHODS}

Isolation and incubation. Bone resorption was measured in 5-day cultures of the midshafts of the radius and ulna of 19-day-old fetal rats with a modification of the technique of Raisz and Niemann (13). 18-day pregnant Sprague-Dawley rats (Charles River Breeding Laboratories, Inc., Wilmington, Mass.) were injected with either $0.2 \mathrm{mCi}$ of ${ }^{45} \mathrm{Ca}(22 \mathrm{Ci} / \mathrm{g}$, New England Nuclear, Boston, Mass.) $24 \mathrm{~h}$ before sacrifice or $2 \mathrm{mCi}$ of $\left[{ }^{3} \mathrm{H}\right]$ proline $(30 \mathrm{Ci} / \mathrm{mM}$, New England Nuclear) 24 and $18 \mathrm{~h}$ before sacrifice. The animals were sacrificed by cervical dislocation and the fetuses were removed. Calcified midshafts of the radius and ulna of both forelimbs were dissected free of the cartilaginous epiphyses and adherent tissue, and then washed at $4^{\circ} \mathrm{C}$ in BGJb medium (Grand Island Biological Co., Grant Island, N. Y.) (14). "Killed" rudiments were prepared by freeze-thawing three times after preculture. Individual rudiments were placed on small rafts of sterilized Millipore filters (Millipore Corp., Bedford, Mass.). These were in turn positioned on stainless steel grids on the surface of a $0.5-\mathrm{ml} \mathrm{BGJb}$ medium supplemented with $4 \mathrm{mg} / \mathrm{ml}$ bovine serum albumin fraction $\mathrm{V}$ (Armour Pharmaceutical Co., Phoenix, Ariz.) in multiwell culture plates (Microbiological Associates, Bethesda, Md.) and preincubated for $24 \mathrm{~h}$ at $37^{\circ} \mathrm{C}$ in an atmosphere of $95 \% \mathrm{O}_{2}, 5 \% \mathrm{CO}_{2}$, at $95-98 \%$ relative humidity. Preincubation media were discarded after $24 \mathrm{~h}$ and the rudiments placed in fresh media containing appropriate concentrations of the test substances. The media were changed again at $48 \mathrm{~h}$ and the incubation continued for a total of 5 days after preculture.

In the ${ }^{45} \mathrm{Ca}$ release studies, the incubation was terminated by placing the rudiments in $0.2 \mathrm{ml}$ of $5 \%$ trichloroacetic acid at room temperature for $3 \mathrm{~h}$. Then $1.0 \mathrm{ml}$ of TS-1 tissue solubilizer (New England Nuclear) was added for an additional $30 \mathrm{~min}$, after which $7 \mathrm{ml}$ of toluene-based scintillation cocktail was added for liquid scintillation counting. 100- $\mu$ l aliquots of 2- and 5-day culture media were dissolved in $0.6 \mathrm{ml}$ TS-1 for $30 \mathrm{~min}$. before the addition of $7 \mathrm{ml}$ of scintillation cocktail. In the $\left[{ }^{3} \mathrm{H}\right]$ proline experiments media aliquots and bones were initially hydrolyzed in $6 \mathrm{~N} \mathrm{HCl}$ (final concentra-

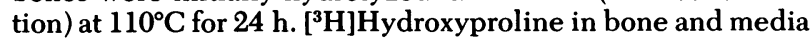
hydrolysates was then determined by the method of Prockop and Udenfriend (15). Percent resorption in both the ${ }^{45} \mathrm{Ca}$ and $\left[{ }^{3} \mathrm{H}\right]$ proline experiments was calculated as: (bone counts per minute/bone counts per minute plus total media counts per minute) $\times 100$. Each data point was comprised of eight or more individual bone rudiment incubations, with the rudiments systematically divided so that equal numbers of radii and ulnae were included in each point. The statistical significance of differences between group means was calculated with a Student's $t$ test.

Cyclic nucleotide generation. In experiments where bone cyclic AMP (cAMP) content was measured, after a 24 -h preculture in control BGJb medium the rudiments were incubated for $24 \mathrm{~h}$ as described above in the presence or absence of the appropriate drug(s). They were then removed from the incubation wells and placed in $12 \times 75$ - $\mathrm{mm}$ glass tubes (four rudiments per tube) containing $0.3 \mathrm{ml}$ of fresh medium and preincubated for $15 \mathrm{~min}$ in room air at $37^{\circ} \mathrm{C}$ in a shaker bath at 90 oscillations $/ \mathrm{min}$. The media were then removed with a transfer pipet and replaced with $0.3 \mathrm{ml}$ of fresh media supplemented with theophylline $(10 \mathrm{mM})$ and containing the test hormone with or without drug. To terminate the reaction, the media were again aspirated off, $0.5 \mathrm{ml}$ of $6 \%$ trichloroacetic acid was added, and the tubes placed in boiling water for $5 \mathrm{~min}$. The tubes were then frozen at $-40^{\circ} \mathrm{C}$ until time of assay. Before assay, the vials were thawed and the bone rudiments disrupted by sonication with two 20-s bursts with a Lab-Line 9100 sonicator (Lab-Line Instruments, Inc., Melrose Park, Ill.), equipped with a microtip and set at $20 \%$ of full scale. The trichloroacetic acid was removed by three extractions with $10 \mathrm{vol}$ of diethyl ether and the residue was blown dry at $60^{\circ} \mathrm{C}$ with a stream of air. For assay, $0.5 \mathrm{ml}$ of 0.05 acetate buffer ( $\mathrm{pH}$ 7.3) was added to the residues and cAMP determined by radioimmunoassay (16) employing a Schwartz/ Mann kit, (Schwartz/Mann Div., Becton, Dickinson \& Co., Orangeburg, N. Y.). Recovery of 1 pmol added standard cAMP ranged from 92 to $106 \%$ and the intra-assay coefficient of variation on replicate samples was $10.6 \%$.

Test materials. The hormones and drugs were initially constituted as stock solutions from which appropriate aliquots were added to the final incubation media. The stock solutions were prepared as follows: synthetic PTH (1-34 Beckman, sp act $3,950 \mathrm{U} / \mathrm{mg}$; Beckman Instruments, Inc., Fullerton, Calif.) was dissolved to a concentration of $400 \mathrm{ng} / \mu \mathrm{l}$ in $0.02 \mathrm{~N} \mathrm{HCl}$ containing $1 \mathrm{mg} / \mathrm{ml}$ bovine serum albumin; synthetic human calcitonin (generously supplied by Armour Pharmaceutical Co., sp act 115 Medical Research Council of Canada U/mg) was dissolved to a concentration of $10 \mu \mathrm{g} / \mathrm{ml}$ directly into BJGb medium; 1,25-dihydroxyvitamin D (generously supplied by Hoffmann-La Roche, Inc., Nutley, N. J.) was dissolved to a concentration of $200 \mathrm{ng} / \mathrm{ml}$ in absolute ethanol; phenobarbital sodium (Elkins-Sinn, Inc., Cherry Hill, N. J.) was dissolved to a concentration of $100 \mathrm{mg} / \mathrm{ml}$ in sterile water; sodium diphenylhydantoin (Sigma Chemical Co., St. Louis, Mo.) was initially dissolved to a concentration of $100 \mathrm{mg} / \mathrm{ml}$ in $0.01 \mathrm{M}$ sodium hydroxide and diluted appropriately with BGJb medium. In all experiments appropriate aliquots of all vehicles were added to control incubations.

\section{RESULTS}

Basal resorption. $\mathrm{DPH}$ at a concentration of 100 $\mu \mathrm{g} / \mathrm{ml}$ significantly inhibited basal ${ }^{45} \mathrm{Ca}$ release from 5-day cultures of bone rudiments, whereas phenobarbital produced significant inhibition only at the highest 
concentration tested, $400 \mu \mathrm{g} / \mathrm{ml}$ (Fig. 1). Control ${ }^{45} \mathrm{Ca}$ release averaged $30.1 \pm 0.8 \%$ whereas freeze-thaw killed bone ${ }^{45} \mathrm{Ca}$ release averaged $14.2 \pm 0.4 \%(P<0.001)$. The difference between these two values represents cell-mediated resorption. Because ${ }^{45} \mathrm{Ca}$ release from killed bones was not significantly altered by DPH or phenobarbital in concentrations up to $400 \mu \mathrm{g} / \mathrm{ml}$, the observed suppressive effects of these agents on ${ }^{45} \mathrm{Ca}$ release must therefore reflect entirely an inhibition of cell-mediated processes.

When employed in combination at submaximal concentrations, DPH and phenobarbital had additive effects on active ${ }^{45} \mathrm{Ca}$ release. The observed inhibition of resorption when DPH $(50 \mu \mathrm{g} / \mathrm{ml})$ was added in combination with phenobarbital (100 or $200 \mu \mathrm{g} / \mathrm{ml}$ ) was virtually identical to what would have been predicted from inhibition produced by each drug individually (Table I).

Hormonally stimulated resorption. The dose-response relationships of mediation of ${ }^{45} \mathrm{Ca}$ release by synthetic PTH (1-34), synthetic human calcitonin (HCT), and 1,25-dihydroxyvitamin $\mathrm{D}_{3}\left[1,25-(\mathrm{OH})_{2} \mathrm{D}\right]$ were examined (Fig. 2). PTH produced a significant increase in ${ }^{45} \mathrm{Ca}$ release at concentrations of $2 \mathrm{ng} / \mathrm{ml}$ and above with maximal resorption achieved at $200 \mathrm{ng} / \mathrm{ml}$. Significant stimulation by $1,25-(\mathrm{OH})_{2} \mathrm{D}$ was seen at a concentration of $0.1 \mathrm{ng} / \mathrm{ml}$ with maximal effect at 5 $\mathrm{ng} / \mathrm{ml}$. PTH-stimulated $(50 \mathrm{ng} / \mathrm{ml})$ resorption was significantly inhibited by HCT at $0.5 \mathrm{ng} / \mathrm{ml}$ and suppression to control values occurred at $20 \mathrm{ng} / \mathrm{ml}$. No alteration of ${ }^{45} \mathrm{Ca}$ release from freeze-killed bones was produced by any of these agents at the highest concentrations employed. In subsequent studies of the effects of DPH and phenobarbital on hormone-mediated resorption, hormone concentrations were em-

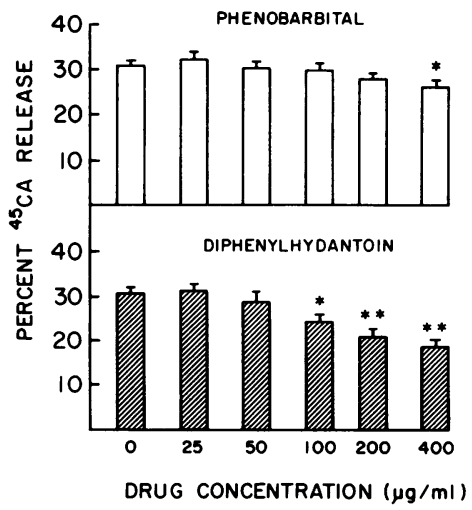

FIGURE 1 Effect of various concentrations of phenobarbital (upper panel) and diphenylhydantoin (lower panel) on ${ }^{45} \mathrm{Ca}$ release from 5-day cultures of forelimb rudiments. Each vertical bar represents the mean $\pm S E M$ of 8-12 incubations. ${ }^{(*)}$ Significantly different from control at $P<0.02$. (**) Significantly different from control at $P<0.01$.
TABLE I

Additivity of Inhibitory Effects of DPH and Phenobarbital on PTH-Induced ${ }^{45} \mathrm{Ca}$ Release

\begin{tabular}{llc}
\hline & \multicolumn{2}{c}{$\begin{array}{c}\text { Inhibition of active } \\
\text { resorption }\end{array}$} \\
\cline { 2 - 3 } & \multicolumn{2}{c}{$\%$} \\
& \multicolumn{3}{c}{ Observed } & Expected \\
DPH, $50 \mu \mathrm{g} / \mathrm{ml}$ & $13.6 \pm 3.0$ & - \\
Phenobarbital, $100 \mu \mathrm{g} / \mathrm{ml}$ & $12.3 \pm 4.2$ & - \\
Phenobarbital, $200 \mu \mathrm{g} / \mathrm{ml}$ & $17.7 \pm 4.7$ & - \\
$\begin{array}{l}\text { DPH, } 50 \mu \mathrm{g} / \mathrm{ml}+\mathrm{phenobarbital}, \\
100 \mu \mathrm{g} / \mathrm{ml}\end{array}$ & $22.3 \pm 5.3$ & 25.9 \\
$\begin{array}{l}\text { DPH, } 50 \mu \mathrm{g} / \mathrm{ml}+\text { phenobarbital, } \\
200 \mu \mathrm{g} / \mathrm{ml}\end{array}$ & $34.5 \pm 8.7$ & 31.3 \\
\hline
\end{tabular}

PTH was present in all incubations at a concentration of 50 $\mathrm{ng} / \mathrm{ml}$. Active resorption was calculated as the difference between live bone and killed bone ${ }^{45} \mathrm{Ca}$ release. Percent inhibition was calculated by comparing observed ${ }^{45} \mathrm{Ca}$ release values to values obtained in the simultaneous control incubations. Expected values were calculated by adding percent inhibition observed in the presence of each agent alone. Values given represent the mean $\pm S E M$ of 8-12 incubations.

ployed which were in the middle of their effective dose ranges.

PTH-induced ${ }^{45} \mathrm{Ca}$ release was significantly reduced by DPH at concentrations of $25 \mu \mathrm{g} / \mathrm{ml}$ and above, whereas phenobarbital was effective in suppressing resorption only at concentrations of $100 \mu \mathrm{g} / \mathrm{ml}$ and higher (Fig. 3). Moreover, at comparable concentrations DPH produced significantly greater inhibition than did phenobarbital; e.g., $100 \mu \mathrm{g} / \mathrm{ml}$ (DPH, $33.9 \pm 3.2 \%$; phenobarbital, 20.8 $\pm 3.6 \%$; $P<0.01$ ), $200 \mu \mathrm{g} / \mathrm{ml}$ (DPH, 51.7 \pm 3.9 ; phenobarbital, $37.0 \pm 4.9 \%$ inhibition of PTH-stimulated value; $P<0.01$ ). Additionally, PTH-stimulated resorption as measured by $\left[{ }^{3} \mathrm{H}\right]$ hydroxyproline release was significantly inhibited by both DPH and phenobarbital (Table II), demonstrating that these agents inhibited matrix resorption as well as ${ }^{45} \mathrm{Ca}$ release. On the other hand, 1,25- $(\mathrm{OH})_{2}$ D-stimulated resorption was somewhat less sensitive to drug inhibition, but significant suppression by DPH occurred at $100 \mu \mathrm{g} / \mathrm{ml}$ whereas phenobarbital was effective only at $200 \mu \mathrm{g} / \mathrm{ml}$ (Fig. 4). Again DPH produced significantly greater inhibition than did phenobarbital at both the $100-$ and $200-\mu \mathrm{g} / \mathrm{ml}$ levels.

Because the drug concentrations employed in these studies were generally higher than those commonly obtained in vivo (17), we examined the question of whether the observed apparent drug suppression of PTH-induced resorption might actually represent irreversible cell toxicity. Incubation in the presence of DPH $(50,100$, or $200 \mu \mathrm{g} / \mathrm{ml})$ or phenobarbital (200 

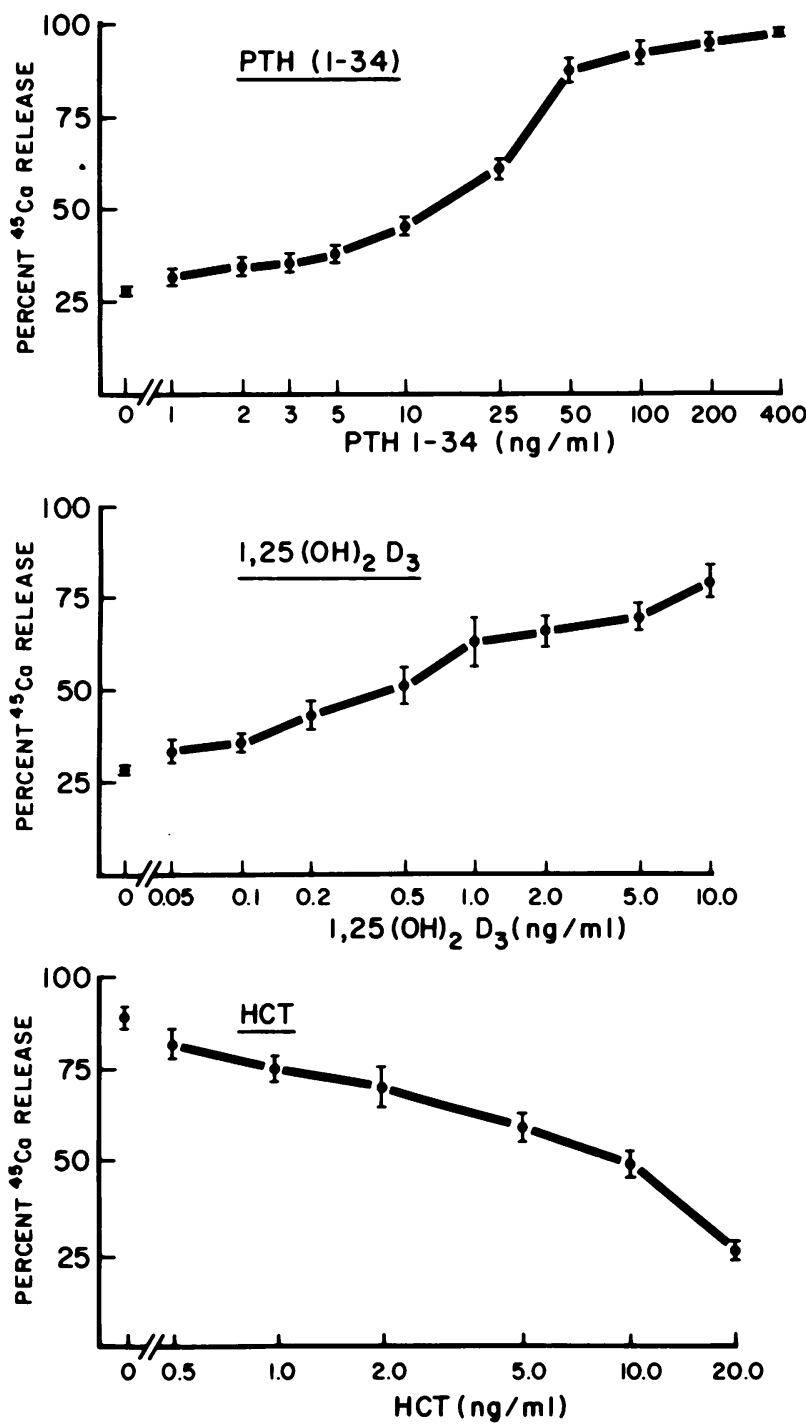

Figure 2 Dose-response curves of ${ }^{45} \mathrm{Ca}$ release from 5-day forelimb rudiment cultures in response to $\mathrm{PTH}, 1,25-(\mathrm{OH})_{2} \mathrm{D}_{3}$, and HCT. The HCT incubations were performed in the presence of PTH $(50 \mathrm{ng} / \mathrm{ml})$ and therefore represent inhibition of PTH-induced resorption. Each point represents the mean $\pm \mathrm{SEM}$ of 8-16 incubations.

$\mu \mathrm{g} / \mathrm{ml}$ ) for $24 \mathrm{~h}$ produced significant inhibition of $\mathrm{PTH}$ induced $(50 \mathrm{ng} / \mathrm{ml})$ resorption, whereas lower concentrations of phenobarbital (100 and $200 \mu \mathrm{g} / \mathrm{ml}$ ) did not produce a significant effect at this early time point (Table III). When pretreated rudiments were then transferred to nondrug-supplemented media containing only PTH $(50 \mathrm{ng} / \mathrm{ml})$, significant inhibition of resorption over the next 2 days was observed only in rudiments which had been exposed to the highest DPH concentration $(200 \mu \mathrm{g} / \mathrm{ml})$. Upon incubation in new media for an additional 2 days no residual inhibition was observed in any group. Thus, the inhibitory effects

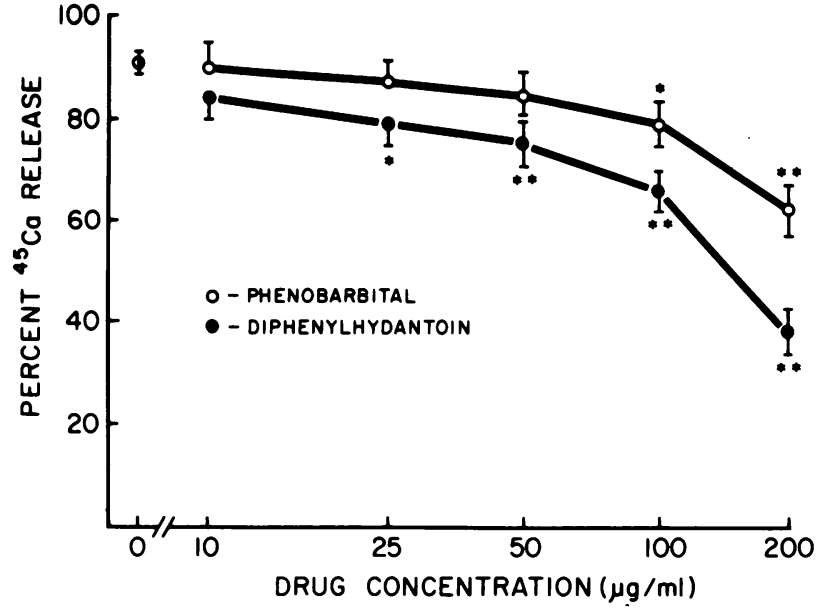

Figure 3 Inhibition of PTH-induced ${ }^{45} \mathrm{Ca}$ release by phenobarbital and diphenylhydantoin in 5-day forelimb rudiment cultures. PTH was present in all incubations at a concentration of $50 \mathrm{ng} / \mathrm{ml}$. Each point represents the mean \pm SEM of 8-16 incubations. $\left({ }^{*}\right)$ Significantly different from control at $P<0.02$. $(* *)$ Significantly different from control at $P<0.01$.

of both agents on PTH-induced resorption were completely reversible and could not be attributed to cell death.

A comparison of the relative effects of DPH and phenobarbital on HCT-mediated ( $5 \mathrm{ng} / \mathrm{ml}$ ) suppression of PTH-stimulated $(100 \mathrm{ng} / \mathrm{ml})$ resorption demonstrated a qualitative difference between the two agents (Fig. 5). DPH significantly inhibited HCT-modulated, PTHinduced resorption at concentrations as low as $10 \mu \mathrm{g} / \mathrm{ml}$, which was $1 / 10$ the concentration of phenobarbital required to produce significant inhibition of resorption under these conditions. Moreover, when DPH and HCT were employed in combination, they appeared to have a greater than additive effect in suppressing

TABLE II

Inhibitory Effect of DPH and Phenobarbital on PTH-Stimulated $\left[{ }^{3} \mathrm{H}\right]$ Hydroxyproline Release from Forelimb Rudiments

\begin{tabular}{lcc}
\hline & $\begin{array}{c}\text { Number of } \\
\text { incubations }\end{array}$ & $\begin{array}{c}\text { Percent } \\
{\left[{ }^{3} \mathrm{H}\right] \text { hydroxyproline }} \\
\text { release }\end{array}$ \\
\hline Control & 10 & $27.8 \pm 2.3$ \\
PTH, $50 \mathrm{ng} / \mathrm{ml}$ & 8 & $86.7 \pm 5.3$ \\
$\begin{array}{l}\text { PTH, } 50 \mathrm{ng} / \mathrm{ml}+\mathrm{DPH}, \\
\quad 100 \mu \mathrm{g} / \mathrm{ml}\end{array}$ & 8 & $60.2 \pm 6.1^{*}$ \\
$\begin{array}{l}\text { PTH, } 50 \mathrm{ng} / \mathrm{ml}+\text { pheno- } \\
\text { barbital, } 200 \mu \mathrm{g} / \mathrm{ml}\end{array}$ & 8 & $64.0 \pm 4.4^{*}$ \\
\hline
\end{tabular}

Values are given as mean $\pm \mathrm{SEM}$.

* Significantly different from PTH-stimulated value at $P<0.01$. 


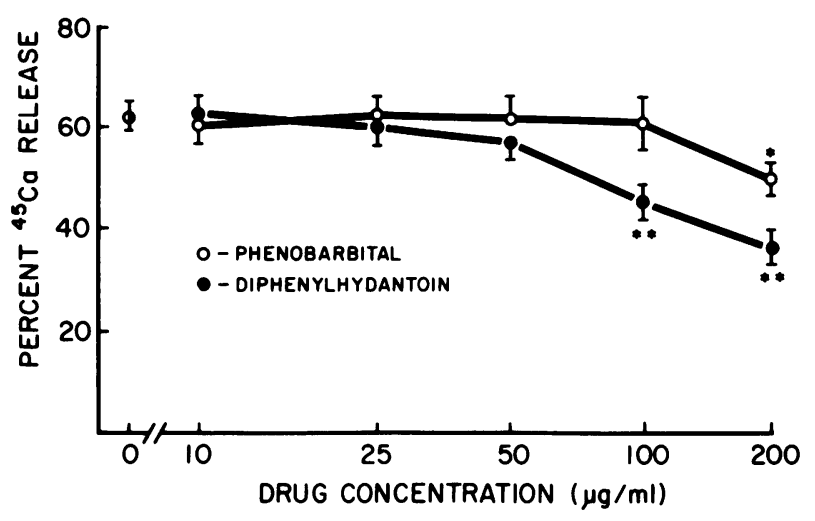

FIGURE 4 Inhibition of $1,25-(\mathrm{OH})_{2} \mathrm{D}_{3}$-induced ${ }^{45} \mathrm{Ca}$ release by phenobarbital and diphenylhydantoin in 5-day forelimb rudiment cultures. $1,25-(\mathrm{OH})_{2} \mathrm{D}_{3}$ was present in all incubations at a concentration of $1 \mathrm{ng} / \mathrm{ml}$. Each point presents the mean \pm SEM of 8-12 incubations. $\left({ }^{*}\right)$ Significantly different from control at $P<0.02$. (**) Significantly different from control at $P<0.01$.

PTH-stimulated resorption. In parallel experiments, the comparative effects of DPH and phenobarbital in suppressing PTH-stimulated ${ }^{45} \mathrm{Ca}$ release in the presence or absence of HCT were examined (Table IV). The data for each agent are expressed as both $(a)$ the absolute percent resorption and $(b)$ the resorption observed in the presence of drug at various concentrations

TABLE III

Effect of Incubation with DPH or Phenobarbital on Subsequent PTH-Stimulated ${ }^{45} \mathrm{Ca}$ Release

\begin{tabular}{lccc}
\hline & \multicolumn{3}{c}{ Incubation days } \\
\cline { 2 - 4 } $\begin{array}{c}\text { Initial incubation } \\
\text { conditions }\end{array}$ & $1-2$ & $2-4$ & $4-6$ \\
\hline Control & $12.6 \pm 1.0$ & $42.4 \pm 2.1$ & $13.1 \pm 1.0$ \\
DPH, $200 \mu \mathrm{g} / \mathrm{ml}$ & $3.9 \pm 0.3^{*}$ & $26.5 \pm 3.0 \ddagger$ & $15.7 \pm 1.1$ \\
DPH, $100 \mu \mathrm{g} / \mathrm{ml}$ & $7.1 \pm 0.6^{*}$ & $35.4 \pm 2.7$ & $15.6 \pm 1.1$ \\
DPH, $50 \mu \mathrm{g} / \mathrm{ml}$ & $9.2 \pm 0.8 \S$ & $43.5 \pm 2.6$ & $14.6 \pm 0.7$ \\
$\begin{array}{c}\text { Phenobarbital, } \\
\quad 400 \mu \mathrm{g} / \mathrm{ml}\end{array}$ & $9.9 \pm 0.8 \S$ & $41.2 \pm 3.4$ & $14.1 \pm 1.0$ \\
$\begin{array}{c}\text { Phenobarbital, } \\
200 \mu \mathrm{g} / \mathrm{ml}\end{array}$ & $10.9 \pm 1.1$ & $43.1 \pm 2.7$ & $13.2 \pm 1.0$ \\
$\begin{array}{c}\text { Phenobarbital, } \\
\quad 100 \mu \mathrm{g} / \mathrm{ml}\end{array}$ & $11.1 \pm 1.0$ & $41.1 \pm 2.2$ & $15.2 \pm 1.1$
\end{tabular}

After a 24-h preincubation in control media, rudiments were initially incubated for $24 \mathrm{~h}$ in control or drug-supplemented media containing PTH (50 ng/ml) (days 1-2). Subsequently, all rudiments were transferred to medium containing PTH $(50 \mathrm{ng} / \mathrm{ml})$ without added drug. Media were changed at $48 \mathrm{~h}$ intervals over the next 4 days and ${ }^{45} \mathrm{Ca}$ release for each subsequent 2 day period (days 2-4 and 4-6) was determined as described in Methods. Values represent the mean \pm SEM for 18-20 incubations.

* Significantly different from control at $P<0.001$.

$\$$ Significantly different from control at $P<0.01$.

$\S$ Significantly different from control at $P<0.05$.

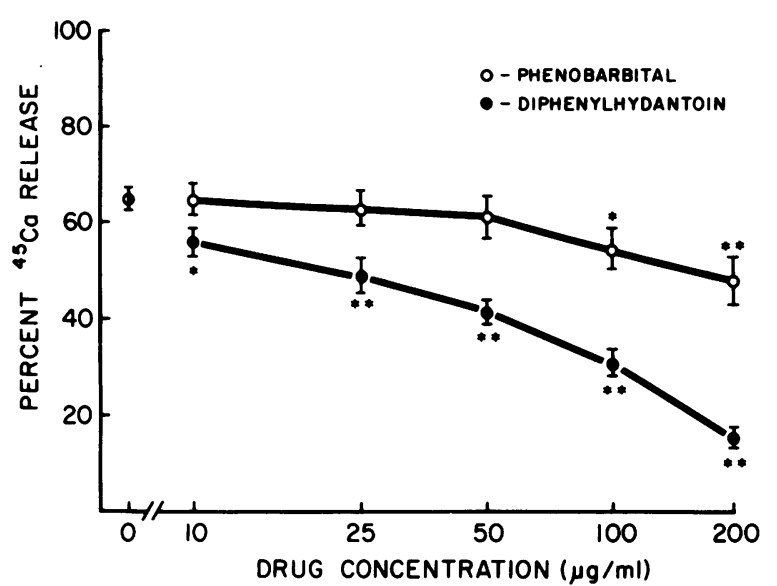

FIgURE 5 Inhibition of PTH plus HCT mediated ${ }^{45} \mathrm{Ca}$ release by phenobarbital and diphenylhydantoin in 5-day forelimb rudiment cultures. PTH $(50 \mathrm{ng} / \mathrm{ml})$ and HCT $(5 \mathrm{ng} / \mathrm{ml})$ were present in all incubations. Each point represents the mean \pm SEM of 8-12 incubations. (*) Significantly different from control at $P<0.02$. (**) Significantly different from control at $P<0.01$.

expressed as a percentage of resorption observed when only PTH or PTH plus HCT alone were present. If the effects of the drug were additive to the effect of HCT, then for any given concentration of added drug resorption expressed as a percent of resorption seen in the absence of added drug should be identical for both the PTH and the PTH plus HCT incubations. This appeared to be the case for phenobarbital in concentrations ranging from 10 to $200 \mu \mathrm{g} / \mathrm{ml}$.

In contrast, DPH in concentrations of $25-200 \mu \mathrm{g} / \mathrm{ml}$ produced a significant, disproportionately greater percent inhibition of resorption in the presence of HCT. When the data were expressed as percent inhibition of active resorption (live bone minus killed bone resorption values) the synergism of effect was even more striking (Fig. 6). This synergism of action strongly suggests that DPH and HCT act at separate but interrelated sites in the cell-mediated resorption process. Additionally, the qualitative differences between the DPH and phenobarbital interactions with HCT suggest that these two drugs produce their effects on different and biochemical distinct aspects of the resorption process.

cAMP generation. After a 30 -min incubation at $37^{\circ} \mathrm{C}$ in $\mathrm{BGJb}$ media containing $10 \mathrm{mM}$ theophylline, control bone rudiment cAMP content averaged $0.71 \pm 0.08 \mathrm{pM} / 4$ rudiments. After the addition of PTH $(100 \mathrm{ng} / \mathrm{ml})$ cAMP content rose rapidly, reaching a plateau at $\cong 4 \frac{1}{2}$ times basal levels by 7 min and remaining constant at this level through $20 \mathrm{~min}$ of exposure. Based on these results, a 7-minute incubation period was employed for all subsequent studies.

Preincubation in the presence of DPH $(200 \mu \mathrm{g} / \mathrm{ml})$ 
TABLE IV

Differential Interaction of Diphenylhydantoin and Phenobarbital with HCT-Mediated Suppression of PTH-Induced Resorption as Measured by ${ }^{45} \mathrm{Ca}$ Release

\begin{tabular}{|c|c|c|c|c|c|}
\hline \multirow[b]{2}{*}{$\begin{array}{c}\text { Drug } \\
\text { concentration }\end{array}$} & \multicolumn{2}{|c|}{ PTH } & \multicolumn{2}{|c|}{ PTH + HCT } & \multirow{2}{*}{$\begin{array}{l}\text { Difference } \\
\text { percent basal } \\
\text { resorption }\end{array}$} \\
\hline & $\begin{array}{l}\text { Absolute } \\
\text { resorption }\end{array}$ & $\begin{array}{c}\text { Basal } \\
\text { resorption }\end{array}$ & $\begin{array}{l}\text { Absolute } \\
\text { resorption }\end{array}$ & $\begin{array}{c}\text { Basal } \\
\text { resorption }\end{array}$ & \\
\hline$\mu g / m l$ & $\%$ & $\%$ & $\%$ & $\%$ & $P$ \\
\hline \multicolumn{6}{|c|}{ Diphenylhydantoin } \\
\hline 0 & $91.4 \pm 4.3$ & $(100)$ & $64.9 \pm 3.4$ & $(100)$ & - \\
\hline 10 & $83.4 \pm 4.7$ & $(91.2 \pm 5.1)$ & $55.8 \pm 3.1$ & $(86.0 \pm 4.7)$ & NS \\
\hline 25 & $79.7 \pm 3.5$ & $(87.2 \pm 3.9)$ & $49.1 \pm 2.1$ & $(75.6 \pm 3.3)$ & $<0.05$ \\
\hline 100 & $66.0 \pm 3.9$ & $(72.2 \pm 3.9)$ & $30.9 \pm 1.7$ & $(47.6 \pm 2.6)$ & $<0.001$ \\
\hline 200 & $38.3 \pm 3.8$ & $(41.9 \pm 4.2)$ & $15.8 \pm 1.0$ & $(24.4 \pm 1.6)$ & $<0.001$ \\
\hline \multicolumn{6}{|l|}{ Phenobarbital } \\
\hline 0 & $91.4 \pm 4.3$ & $(100)$ & $64.9 \pm 3.4$ & $(100)$ & - \\
\hline 10 & $89.9 \pm 5.1$ & $(98.4 \pm 5.6)$ & $64.6 \pm 2.0$ & $(99.5 \pm 3.1)$ & NS \\
\hline 25 & $87.3 \pm 3.9$ & $(95.5 \pm 4.3)$ & $63.3 \pm 2.2$ & $(97.5 \pm 3.4)$ & NS \\
\hline 50 & $84.9 \pm 4.0$ & $(92.9 \pm 4.4)$ & $61.6 \pm 3.1$ & $(94.9 \pm 4.7)$ & NS \\
\hline 100 & $79.2 \pm 3.9$ & $(86.7 \pm 4.2)$ & $54.3 \pm 3.3$ & $(83.7 \pm 5.1)$ & NS \\
\hline 200 & $61.9 \pm 4.8$ & $(67.7 \pm 5.3)$ & $48.1 \pm 3.2$ & $(74.1 \pm 5.0)$ & NS \\
\hline
\end{tabular}

Values are given for resorption observed in the presence of various concentrations of drug expressed both as absolute percent resorption and as a percent of the resorption observed in the absence of added drug. Basal resorption is defined as the ${ }^{45} \mathrm{Ca}$ release occurring in the presence of hormone without added drug and is arbitrarily set at $100 \%$ for both the PTH and PTH plus HCT $5 \mathrm{ng} / \mathrm{ml}$. Values represent the mean \pm SEM of 8-12 incubations.

or phenobarbital $(400 \mu \mathrm{g} / \mathrm{ml})$ for $24 \mathrm{~h}$ did not significantly alter basal cAMP content (Table V). However, the increase in cAMP content produced by incubation with PTH at a concentration of $100 \mathrm{ng} / \mathrm{ml}$ was reduced by $38 \%$ by DPH $(200 \mu \mathrm{g} / \mathrm{ml})$ whereas phenobarbital $(400 \mu \mathrm{g} / \mathrm{ml})$ was without significant effect. HCT at a concentration of $5 \mathrm{ng} / \mathrm{ml}$ significantly increased both basal and PTH-stimulated cAMP content (Table V), confirming previous reports of the additive effects of PTH and HCT in stimulating cAMP content in intact rat calvaria and in bone cells isolated from fetal rat calvaria $(18,19)$. DPH at a concentration of $200 \mu \mathrm{g} / \mathrm{ml}$ reduced PTH plus HCT-stimulated cAMP content by $36 \%$, a percentage reduction very similar to that produced by DPH in the presence of PTH alone (Table V). This latter observation is in marked contrast to the striking synergistic effect of DPH with HCT in inhibiting ${ }^{45} \mathrm{Ca}$ release at these same drug and hormone concentrations (Table IV, Figs. 5 and 6). These data would therefore suggest that DPH and HCT have additional direct inhibitory effects on bone resorption which are not mediated through inhibition of cAMP generation, and that it is at the cAMP unrelated site that DPH and HCT produce their synergistic effect. Phenobarbital produced a slight, but not statistically significant, reduction in PTH-HCT-stimulated cAMP formation, similar to its effects in the presence of PTH alone.

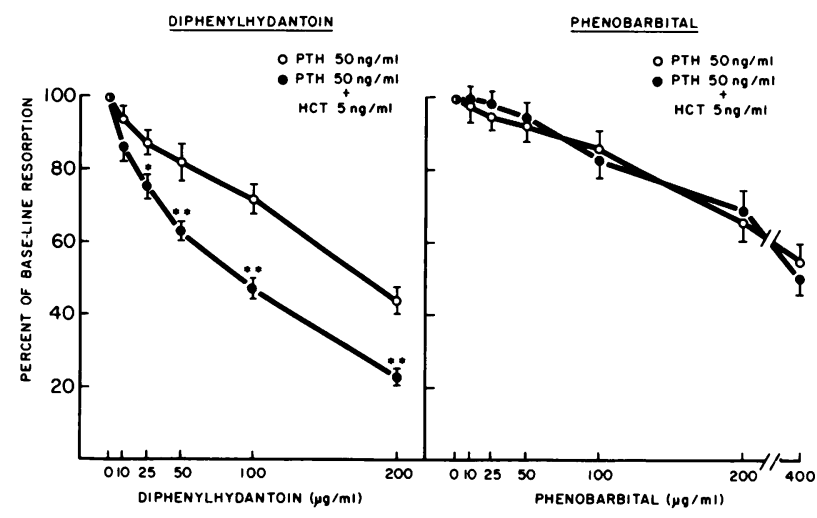

Figure 6 Inhibition by phenobarbital and diphenylhydantoin of active (cell-mediated) PTH and PTH plus HCT induced ${ }^{45} \mathrm{Ca}$ release in 5-day forelimb rudiment cultures. Active resorption was determined by subtracting values for ${ }^{45} \mathrm{Ca}$ release in identically cultured "killed" bones (see Methods) from the values obtained for cultured live bones. Baseline resorption is defined as the ${ }^{45} \mathrm{Ca}$ release occurring in the presence of hormone without added drug, and is arbitrarily set at $100 \%$ for both the PTH and PTH plus HCT incubations. The observed ${ }^{45} \mathrm{Ca}$ release in the presence of added drug at various concentration is plotted as a percent of baseline resorption. If the effects of HCT and the test drug are additive, the lines should overlap. Each point represents the mean \pm SEM of 8-16 incubations. (*) Significantly different from PTH-only value at $P<0.01$. (**) Significantly different from PTH-only value at $P<0.001$. 
TABLE V

Effects of DPH and Phenobarbital on cAMP Generation in Fetal Forelimb Rudiments

\begin{tabular}{lccc}
\hline & $\begin{array}{c}\text { Number } \\
\text { of incu- } \\
\text { bations }\end{array}$ & cAMP & $\begin{array}{c}P \text { value } \\
\text { vs. control }\end{array}$ \\
\hline & & $p$ M/4 rudiments & \\
Control & 16 & $0.70 \pm 0.06$ & - \\
DPH & 10 & $0.64 \pm 0.10$ & NS \\
Phenobarbital & 10 & $0.69 \pm 0.08$ & NS \\
& & & vs. PTH \\
PTH & 16 & $3.18 \pm 0.12$ & - \\
PTH + DPH & 10 & $1.98 \pm 0.19$ & $<0.001$ \\
PTH + phenobarbital & 10 & $2.94 \pm 0.21$ & NS \\
& & & vs. Control \\
Control & 16 & $0.72 \pm 0.07$ & - \\
PTH & 14 & $3.30 \pm 0.11$ & $<0.001$ \\
HCT & 10 & $1.02 \pm 0.09$ & $<0.02$ \\
& & & vs. PTH \\
\hline PTH + HCT & 10 & $3.67 \pm 0.13$ & $<0.05$ \\
& & & vs. PTH + HCT \\
PTH + HCT + DPH & 10 & $2.34 \pm 0.21$ & $<0.001$ \\
PTH + HCT & 10 & $3.18 \pm 0.24$ & NS \\
\hline & & &
\end{tabular}

cAMP content was determined as described in Methods after a 7-min incubation in the presence of test hormone and drug or vehicle, after a 24 -h preincubation in the presence of drug or vehicle alone. Theophylline $(10 \mathrm{mM})$ was present during the final $7 \mathrm{~min}$ of all incubation. Concentrations employed were: DPH, $200 \mu \mathrm{g} / \mathrm{ml}$; phenobarbital, $400 \mu \mathrm{g} / \mathrm{ml}$; PTH, 100 $\mathrm{ng} / \mathrm{ml}$; and HCT, $5 \mathrm{ng} / \mathrm{ml}$. Values represent the mean $\pm \mathrm{SEM}$ of pooled data from two experiments.

\section{DISCUSSION}

The results of these studies demonstrate that both DPH and phenobarbital are capable of altering basal and hormonally mediated bone resorption processes. Both drugs were demonstrated to significantly inhibit basal, PTH-stimulated and 1,25- $(\mathrm{OH})_{2}$ D-stimulated resorption. The observation that both ${ }^{45} \mathrm{Ca}$ and $\left[{ }^{3} \mathrm{H}\right]$ hydroxyproline release were suppressed by these agents indicates that the resorption of both mineral and protein matrix were affected. DPH was a considerably more potent inhibitory agent than was phenobarbital, producing suppression of PTH-induced resorption at concentrations as low as $10 \mu \mathrm{g} / \mathrm{ml}$. This concentration is well within the usual serum therapeutic range of $10-25 \mu \mathrm{g} / \mathrm{ml}$ (17). However, DPH in serum is $\cong 90 \%$ protein bound (20) and as a result of the considerably lower concentration of protein present in the incubation medium relative to that in human serum, it is probable that the free DPH concentration in our cultures was higher than that occurring in vivo. On the other hand, because the drug effect was definitely dose-related over a 20 -fold concentration range in vitro, it might be expected that lower concentrations acting over a longer time would produce effects in vivo similar to those observed in vitro.

Although DPH and phenobarbital at submaximal concentrations were additive with regard to their inhibitory effects on resorption as assessed by ${ }^{45} \mathrm{Ca}$ release, our data suggest that they may act at different sites in the resorption process. Whereas phenobarbital was merely additive to the inhibitory effect of HCT on PTH-induced resorption, DPH exhibited a synergistic interaction with HCT. This suggests that: $(a)$ DPH and HCT act at separate but interrelated sites in the resorption process; and $(b)$ the modes of action DPH and phenobarbital may be dissimilar.

It is apparent that both DPH and phenobarbital inhibit bone resorption through cAMP-independent mechanisms because both agents inhibited $1,25-(\mathrm{OH})_{2} \mathrm{D}$ induced resorption, a process previously shown to be independent of cAMP $(21,22)$. However, in contrast to phenobarbital, DPH had additional effect on cAMP generation. DPH at a concentration of $200 \mu \mathrm{g} / \mathrm{ml}$ partially suppressed PTH-stimulated increases in rudiment cAMP content whereas phenobarbital at concentrations as high as $400 \mu \mathrm{g} / \mathrm{ml}$ had no statistically significant effects on cAMP generation. Because the stimulation of cAMP formation has been postulated to play an important role in PTH mediation of bone resorption (23-25) and because dibutyryl cAMP has been shown to mimic the resorptive effect of PTH on bone (25), it is therefore possible that DPH may inhibit PTH-induced bone resorption through both cAMP-dependent and independent mechanisms.

The synergistic effect of DPH and HCT in suppressing PTH-stimulated ${ }^{45} \mathrm{Ca}$ release is apparently not mediated through synergistic effects on cAMP generation. In initial experiments, we demonstrated that PTH and HCT both increased cAMP in intact long bone rudiments and that their effects on cAMP generation in this system were additive. These observations are in agreement with previous reports of the additive effects of PTH and calcitonin on cAMP generation in intact rat calvaria and in bone cells isolated from fetal rat calvaria $(18,19)$. However, it was subsequently demonstrated that both PTH and PTH plus HCTstimulated cAMP generation were inhibited to a similar degree by DPH. Thus, the synergistic interaction of DPH and HCT apparently occurs through mechanisms independent of cAMP generation.

Jenkins and co-workers (26) have reported that DPH, but not phenobarbital, inhibits parathyroid extractstimulated ${ }^{45} \mathrm{Ca}$ release from cultured mouse calvaria. 
However, they were unable to demonstrate any effect of DPH on cAMP generation. The basis for the divergence of these results from the findings of the present studies is unclear, but could be the result of species differences, recently demonstrated differences in the responsitivity of calvaria and long bones to certain resorptive stimuli (27), or merely to differences in the concentrations of drug employed.

The precise mechanism by which DPH inhibits PTH-stimulated cAMP generation is at present undefined. It has been demonstrated that PTH stimulates calcium entry into bone cells, an effect which has been postulated to be important in the production of its biologic effects $(28,29)$. This view is supported by the observation that calcium ionophore A23187, which has been shown to stimulate calcium uptake by bone cells in vitro (29), can mimic certain of the effects of PTH on bone in vitro including stimulation of cAMP generation and enhancement of resorption $(29,30)$. In this regard, it is of note that the anticonvulsant action of DPH has been shown to be mediated through suppression of post-tetanic potentiation, a process that is associated with the movement of calcium ions into the presynaptic area during stimulation (31). This suppressive effect appears to be due primarily to an alteration in membrane transport of sodium ion with an indirect diminution of calcium influx (32). Because there is evidence that transmembrane movement of sodium ion plays an important role in the cellular transport of calcium ion in both intestine and bone (33-35), it could well be that DPH inhibition of membrane permeability to sodium reduces transmembrane calcium transport in these tissues as well. In support of this view, DPH has been shown to directly inhibit intestinal calcium transport in vivo under conditions in which vitamin D metabolism is apparently not altered (12). Thus, the effect of DPH on PTH-induced cAMP generation could well occur via inhibitory effects on PTH-induced changes in intracellular calcium ion concentration. A similar inhibitory effect of DPH on calcium influx and stimulated cAMP generation has recently been demonstrated in mouse brain in vitro (36). In addition, because calcitonin inhibits the efflux of calcium ion from bone cells (37), the synergistic interaction of DPH and HCT could occur at the level of membrane transport of calcium ion. Moreover, it has been demonstrated that collagenase, an enzyme which apparently plays an important role in bone matrix dissolution, exhibits an absolute dependence for calcium ion (38). Therefore, it is possible that DPH acts primarily by suppressing cell-mediated calcium release from bone, with a secondary reduction in collagenase activity and consequent inhibition of further matrix resorption.

Finally, the apparent divergent effects of DPH on bone metabolism raises the problem of reconciling the clinical observations that DPH can produce either calvarial thickening and tooth root abnormalities suggestive of diminished PTH effect $(9-11)$ or histologic evidence of increased osteoclastic activity in association with a classic histologic pattern of osteomalacia (1). Based on our present findings that DPH directly inhibits basal and hormonally stimulated resorption in long bone in vitro, one might anticipate primarily an osteosclerotic response to DPH administration. However, several additional variables must be considered. First, the direct effect of DPH on bone formation remains to be defined. If DPH has an inhibitory effect on formation as well as resorption it would be anticipated that the balance between effects on formation and resorption would determine the predominant clinical manifestation. Furthermore, with regard to anticonvulsant drug-induced tooth root abnormalities, it is possible that the various calcified tissue exhibit different responses to DPH. In support of this viewpoint, an increased incidence of root abnormalities characteristic of hypothyroidism has been observed in epileptic populations demonstrated to have clinical and histologic evidence of osteomalacia and secondary hyperparathyroidism $(9,10)$. Finally, it is conceivable that the predominant osseus response to DPH is conditioned by the status of vitamin $\mathrm{D}$ nutrition. If vitamin $D$ input through dietary intake and sunlight exposure were sufficient to overcome drug-induced reductions in levels of active vitamin D metabolites (7), decreased bone resorption might be the predominant effect of DPH. Where vitamin D input was not sufficient to maintain adequate concentrations of active vitamin D metabolites, then osteomalacia and evidence of secondary hypoparathyroidism might predominate. Additional investigation of the interactions of DPH with hormonally mediated formation and resorption processes in the various calcified tissues will be necessary to resolve these questions.

\section{ACKNOWLEDGMENTS}

We would like to thank Dr. Lawrence A. Raisz for his generous assistance and encouragement. Additional expert technical assistance was provided by Mrs. Linda Eisenkramer and Mrs. Joann Hamilton.

This work was supported in part by National Institutes of Health grants NS10262, AM11674, and a research grant from The March of Dimes National Foundation.

\section{REFERENCES}

1. Richens, A., and D. J. F. Rowe. 1970. Disturbance of calcium metabolism by anticonvulsant drugs. $\mathrm{Br}$. Med. J. 3: 73-76.

2. Dent, C. E., A. Richens, D. J. F. Rowe, and T. C. B. Stamp. 1970. Osteomalacia with long-term anticonvulsant therapy in epilepsy. Br. Med.J. 4: 69-72. 
3. Hunter, J., J. D. Maxwell, D. A. Stewart, V. Parsons, and R. Williams. 1971. Altered calcium metabolism in children on anticonvulsants. Br. Med. J. 2: 202-204.

4. Hahn, T. J., B. A. Hendin, C. R. Scharp, V. C. Boisseau, and J. G. Haddad, Jr. 1975. Serum 25-hydroxycalciferol levels and bone mass in children on chronic anticonvulsant therapy. N. Engl. J. Med. 292: 550-554.

5. Tolman, K. G., W. Jubiz, J. J. Sannella, and J. A. Madsen. 1975. Osteomalacia associated with anticonvulsant drug therapy in mentally retarded children. Pediatrics. 56: 45-51.

6. Bouillion, R., J. Reynaut, J. G. Claes, W. Lissens, and P. DeMoor. 1975. The effect of anticonvulsant therapy on serum levels of 25-hydroxyvitamin D, calcium and parathyroid hormone. J. Clin. Endocrinol. Metab. 41: 1130-1136.

7. Hahn, T. J., S. J. Birge, C. R. Scharp, and L. V. Avioli. 1972. Phenobarbital-induced alterations in vitamin D metabolism. J. Clin. Invest. 51: 741-748.

8. Silver, J., G. Neale, and G. R. Thompson. 1974. Effect of phenobarbitone treatment on vitamin $\mathrm{D}$ metabolism in mammals. Clin. Sci. Mol. Med. 46: 433-448.

9. Harris, M., M. V. Jenkins, and M. R. Wills. 1974. Phenytoin inhibition of parathyroid hormone induced bone resorption in vitro. J. Pharmacol. (Paris). 50: 405-408.

10. Harris, M., and P. Goldhaber. 1974. Root abnormalities in epileptics and the inhibition of parathyroid hormone induced bone resorption by diphenyl hydantoin in tissue culture. Arch. Oral Biol. 19: 981-984.

11. Kattan, K. R. 1970. Calvarial thickening after dilantin medication. Am. J. Roentgenol. Radium Ther. Nucl. Med. 110: $102-105$

12. Koch, H. V., D. Kraft, and D. von Herrath. 1972. Influence of diphenylhydantoin and phenobarbital on intestinal calcium absorption in the rat. Epilepsia. 13: 829-841.

13. Raisz, L. G., and I. Niemann. 1969. Effect of phosphate, calcium and magnesium on bone resorption and hormonal response in tissue culture. Endocrinology. 85: 446-452.

14. Biggers, J. D., R. B. L. Gwatkin, and S. Heyner. 1961. Growth of embryonic avian and mammalian tibiae on a relatively simple chemically defined medium. Exp. Cell Res. 24: 41-58.

15. Prockop, D. J., and S. Udenfriend. 1960. A specific method for the analysis of hydroxyproline in tissues and urine. Anal. Biochem. 1: 228-237.

16. Steiner, A. L., D. M. Kipnis, R. Utiger, and C. Parker. 1969. Radioimmunoassay for the measurement of adenosine $3^{\prime} 5^{\prime}$ cyclic phosphate. Proc. Natl. Acad. Sci. U. S. A. 64: $367-373$.

17. Nordentoft-Jensen, B., and V. Grynderup. 1966. Studies on the metabolism of phenytoin. Epilepsia. 7: 238-245.

18. Johannes, N., M. Heersche, R. Marcus, and G. D. Aurbach. 1974. Calcitonin and the formation of $3^{\prime} 5^{\prime}$ AMP in bone and kidney. Endocrinology. 94: 241-247.

19. Smith, D. M., and C. C. Johnston, Jr. 1974. Hormonal responsiveness of adenylate cyclase activity from separated bone cells. Endocrinology. 95: 130-139.

20. Lund, L., A. Berlin, and P. K. M. Lunde. 1972. Plasma protein binding of diphenylhydantoin in patients with epilepsy: agreement between the unbound fraction in plasma and the concentration in cerebrospinal fluid. Clin. Pharmacol. Ther. 13: 196-200.
21. Peck, W. A., and I. Dowling. 1976. Failure of 1,25-dihydroxycholecalciferol to modify cyclic AMP levels in parathyroid hormone treated and untreated bone cells. Endocr. Res. Commun. 3: 157-166.

22. Wong, G. L., R. A. Luben, and D. V. Cohn. 1977. 1,25dihydroxycholecalciferol and parathormone: effects on isolated osteoclast-like and osteoblast-like cells. Science (Wash. D. C.). 197: 663-665.

23. Chase, L. R., and G. D. Aurbach. 1970. The effect of parathyroid hormone on the concentration of adenosine $3^{\prime} 5^{\prime}$ monophosphate in skeletal tissue in vitro. J. Biol. Chem. 245: 1520-1526.

24. Rodan, S., and G. Rodan. 1974. The effect of parathyroid hormone and thyrocalcitonin on the accumulation of cyclic adenosine $3^{\prime} 5^{\prime}$ monophosphate in freshly isolated bone cells. J. Biol. Chem. 249: 3068-3074.

25. Klein, D. C., and L. G. Raisz. 1971. Role of adenosine 3'5'-monophosphate in the hormonal regulation of bone resorption: studies with cultured fetal bone. Endocrinology. 89: 818-826.

26. Jenkins, M. V., M. Harris, and M. R. Willis. 1974. The effects of phenytoin on parathyroid extract and 25-hydroxycholecalciferol-induced bone resorption: adenosine 3'5' cyclic monophosphate production. Calcif. Tissue Res. 16: 163-167.

27. Ivey, J. L., D. R. Wright, and A. H. Tashjian, Jr. 1976. Bone resorption in organ culture. Inhibition by the divalent cation ionophores A23187 and X537A. J. Clin. Invest. 58: 1327-1338.

28. Dziak, R., and P. H. Stern. 1975. Calcium transport in isolated bone cells. II. Effects of parathyroid hormone and cyclic 3'5' AMP. Endocrinology. 97: 1281-1287.

29. Dziak, R., and P. H. Stern. 1976. Response of fetal rat bone cells and bone organ cultures to the ionophore A23187. Calcif. Tissue Res. 22: 137-147.

30. Reed, P. W., and H. A. Lardy. 1972. A23187: a divalent cation ionophore. Fed. Proc. 31: 432-438.

31. Calne, D. B. 1973. The Drug Treatment of Epilepsy. Br. J. Hosp. Med. 9: 171-175.

32. Pincus, J. H. 1972. Diphenylhydantoin and ion flex in lobster nerve. Arch. Neurol. 26: 4-10.

33. Martin, D. L., and H. F. DeLuca. 1969. Influence of sodium on calcium transport by the rat small intestine. Am. J. Physiol. 216: 1351-1359.

34. Birge, S. J., Jr., H. R. Gilbert, and L. V. Avioli. 1972. Intestinal transport: the role of sodium. Science (Wash. D. C.). 176: $168-170$.

35. Wills, M. R. 1973. Calcium homeostasis in health and disease. In Recent Advances in Medicine. D. N. Baron, N. Compston, and A. M. Dawson, editors. Churchill (J. A.) Ltd., London. 16th edition. 65.

36. Ferrendelli, J. A., and D. A. Kenscherf. 1977. Phenytoin: effects on calcium flux and cyclic nucleotides. Epilepsia. 18: $331-336$.

37. Harrell, A., I. Binderman, and G. A. Rodan. 1973. The effect of calcium concentration on calcium uptake by bone cells treated with thyrocalcitonin hormone. Endocrinology. 92: 550-555.

38. Seltzer, J. L., H. G. Welgus, J. J. Jeffrey, and A. Z. Eisen. 1976. The function of $\mathrm{Ca}^{2+}$ in the action of mammalian collagenases. Arch. Biochem. 173: 355-361. 